\title{
Content and Structure of Bachelor's Training within the Dual Education System: Ukrainian and German Experience
}

\author{
Dmytro Khrapach \\ Postgraduate Student, Khmelnytskyi National University, \\ (Khmelnitsky, Ukraine) \\ Hanna Krasylnykova \\ Doctor of Science in Pedagogy, Associate Professor \\ Khmelnytskyi National University (Khmelnitsky, Ukraine)
}

\begin{abstract}
The comparative analysis of Ukrainian and foreign experience of creating dual Bachelor's education programs in Automotive Technology has been conducted in the article. The structure and content of the Bachelor's education programs in Automotive Technology provided by the leading Ukrainian higher education institutions have been characterized. The main types of practices have been identified as components of education programs aimed at practical training of the future Bachelors in Automotive Technology. The algorithm of creating educational training programs within the dual education system by mastering a number of special disciplines at higher education institutions has been highlighted. The German experience of creating dual training programs for the Bachelors in Automotive Technology is presented in the article. The implementation of the dual training programs takes place according to two models of dual training: trainingoriented or practical-integrated training. The key features of implementation of dual models are characterized: training-oriented - continuous practical training at the enterprise combined with the theoretical training at the educational institution; practical-integrated training - alternating periods of practical training at the enterprise and training at the educational institution. The advantages of using dual training programs of the future Bachelors in Automotive Technology are identified and the prospects for further development of dual higher education in Ukraine are highlighted.
\end{abstract}


Keywords: higher education, dual form of education, dual program, curriculum structure.

Постановка проблеми. Наріжними проблемами вітчизняної вищої освіти $є$ iii відірваність від потреб ринку праці, незадоволення стейхолдерів змістом та рівнем якості підготовки фахівців відповідно до вимог сучасного виробництва. 3 веденням в дію «Положення про дуальну форму здобуття вищої та фахової передвищої освіти» [1] заклади вищої освіти (3ВО) можуть реорганізувати практичну складову освітнього процесу на основі нових стандартів вищої освіти та освітньо-професійних програм (ОПП), і таким чином, усунути існуючі проблеми. Відтак, у ЗВО виникає нагальна потреба розроблення та створення практико-орієнтованих ОПП, так званих дуальних програм підготовки фахівців різних спеціальностей. При цьому дуальна програма передбачає поєднання навчання осіб у закладах освіти 3 навчанням на робочих місцях на підприємствах, в установах та організаціях для набуття певної кваліфікації на основі договору.

Досвід розроблення дуальних програм у переважній більшості вітчизняних ЗВО практично відсутній, відтак актуальним є вивчення європейських підходів щодо реалізації дуального навчання, зокрема, Німеччини, в якій дуальна освіта реалізується тривалий час, у тому числі у сфері вищої освіти. Впровадження передового міжнародного досвіду щодо організації практичного навчання в умовах реального вітчизняного виробництва дозволить, на нашу думку: модернізувати вищу освіту та привести іiі у відповідність до сучасних вимог ринку праці, підвищити мотивацію здобувачів вищої освіти до навчання шляхом ï залучення до роботи в умовах реального виробництва на етапі їх навчання та подальшого працевлаштування, підвищення якості підготовки фахівців шляхом посилення ролі роботодавців у процесі їх навчання.

Аналіз останніх досліджень і публікацій. Узагальнення зарубіжного та вітчизняного досвіду щодо розроблення ОПП висвітлено в наукових роботах та методичних виданнях педагогів, які є членами Національної ради експертів 3 
реформування вищої освіти України (В. Захарченко, В. Луговий, Ж. Таланова, Л. Гризун, Ю. Рашкевича) [2]. Так, у роботі Ю. Рашкевича [3] розкрито зміст та структуру опису освітньої програми, в контексті нових стандартів вищої освіти. Дослідження Л. Гризун присвячено формуванню змісту вищої професійної освіти [4]. В.Захарченко висвітлює проблему моніторингу освітніх програм вищої освіти з урахуванням міжнародних стандартів з метою забезпечення їх якості. Оцінювання якості вищої освіти в умовах євроінтеграції охарактеризували у своїх аналітичних матеріалах В. Луговий та Ж. Таланова [5].

Отже, аналіз літературних джерел свідчить про привернення уваги вітчизняних науковців до питань розроблення змісту професійно-практичної підготовки фахівців та його представлення у формі ОПП. Водночас, відсутні наукові розвідки в сфері методології, проектування вітчизняних ОПП за дуальною формую навчання, а також практичний досвід їх реалізації для підготовки майбутніх фахівців різних спеціальностей

Формування цілей статті. Полягає в аналізі структури змістового наповнення ОПП підготовки фахівців професійної освіти (на прикладі спеціальності 015.20 «Професійна освіта. Транспорт»), що реалізуються провідними вітчизняними 3ВО, у порівнянні 3 німецькими дуальними програмами навчання за спеціальностями автотранспортного профілю.

Виклад основного матеріалу. В окремих українських 3ВО впроваджуються традиційні ОПП здобуття вищої освіти за окремими спеціальностями 3 елементами дуального навчання, які розробляться відповідно до рекомендацій Міністерство освіти і науки України [6]. Вітчизняна вища освіта має великий досвід поєднання інституційної теоретичної підготовки майбутніх фахівців 3 навчанням на робочих місцях на підприємстві 3 подальшим набуттям певної робітничої кваліфікації, що фактично є прототипом європейської дуальної освіти [7]. Підготовка бакалаврів професійної освіти автотранспортного профілю відбувається за ОПП, що розрахована на 240 кредитів СКТС та термін навчання 4 роки, а з 2019 року - базується на стандарті вищої освіти 015 «Професійна освіта» [8]. Приклади реалізації таких програм знаходимо у багатьох вітчизняних 
університетах, зокрема Національний транспортний університет (НТУ), Хмельницький національний університет (ХНУ) і Чернігівський національно педагогічний університет імені Т.Г. Шевченка (ЧНПУ) та ін.

Структура освітньої-професійної програми містить два компоненти, з яких нормативний визначається стандартом вищої освіти і є базою для створення навчального плану спеціальності 015.20 «Професійна освіта». Обсяг обов'язкової частини навчального плану для підготовки бакалаврів цієї спеціальності може коливатися у межах 50-75\% від загального обсягу ОПП, та спрямовується на забезпечення формування загальних та спеціальних (фахових) компетентностей. Обсяг вибіркових навчальних дисциплін - становить $25 \%$, він спрямований на реалізацію права студента, відповідно до Закону України «Про вищу освіту» [9], щодо вільного вибору частини навчальних дисциплін відповідно до їх власних освітніх потреб та інтересів.

Обов'язкова частина змісту підготовки бакалаврів професійної освіти автотранспортного профілю реалізується в дисциплінах у двох циклах: загальної підготовки та професійної підготовки. До циклу загальної підготовки входять дисципліни гуманітарного, природничо-наукового спрямування та професійноорієнтовані. Водночас, у циклі професійної підготовки є дисципліни, що забезпечують набуття здобувачами вищої освіти низки спеціальних фахових компетентностей, до яких Каньковський I.С. відносить [10]: ергономічну, технологічну, технічну, кваліметричну, діагностичну, статистичну, експертну, рефлексівну. Безумовно, що серед усіх виокремлених, технологічна компетентность $є$ однією із базових для бакалаврів професійної освіти автотранспортного профілю, основною професійною функцією яких є володіння технологіями діагностування та ремонту автотранспортних засобів. Графічне представлення змісту навчальних планів підготовки бакалаврів професійної освіти автотранспортного профілю у вітчизняних ЗВО подано на рисунках 1-3.

Порівняльний аналіз змісту нормативної частини планів вітчизняних ЗВО дозволив встановити, що загальна підготовки гуманітарного спрямування в університетах реалізується через дисципліни: «Іноземна мова» та «Філософія». 


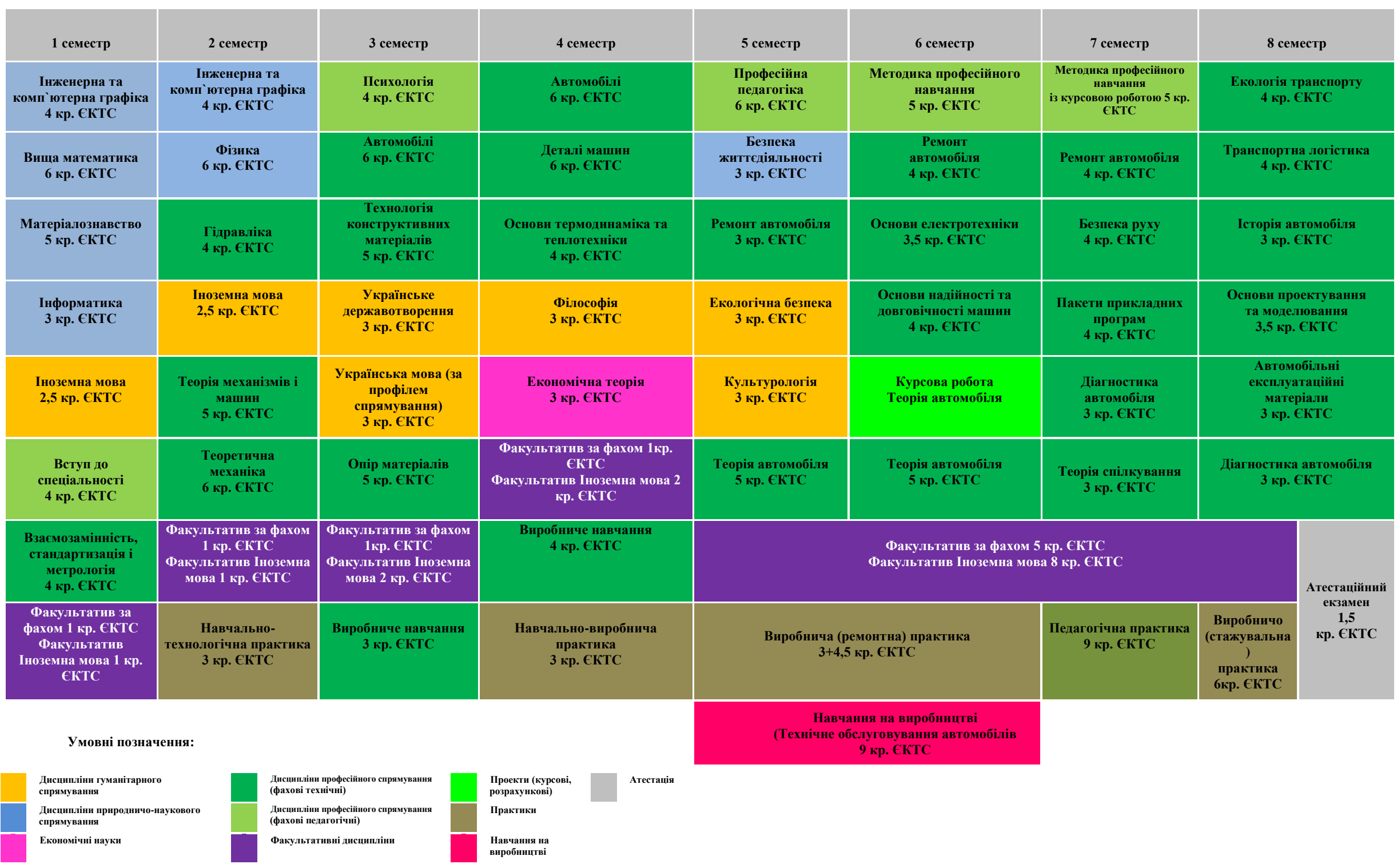

Рисунок 1 - Навчальний план підготовки бакалаврів денної форми навчання спеціальності 015.20 (Професійна освіта. Транспорт) Хмельницького національного університету (обов'язкова частина) [6] 


\begin{tabular}{|c|c|c|c|c|c|c|c|}
\hline 1 семестр & 2 семестр & 3 семестр & 4 семестр & 5 семестр & 6 семестр & 7 семестр & 8 семестр \\
\hline $\begin{array}{c}\text { Вступ до спеціальності } \\
3 \text { кр. ЄКТС }\end{array}$ & $\begin{array}{l}\text { Риторика } \\
\text { З кр. ЄК }\end{array}$ & $\begin{array}{l}\text { Психологія } \\
4,5 \text { кр. ЄкТС }\end{array}$ & $\begin{array}{l}\text { Основи безпеки } \\
\text { людини } \\
4 \text { кр. ЄКТС } \\
\end{array}$ & $\begin{array}{l}\text { Теорія та методика } \\
\text { виховної роботи } \\
3 \text { кр. ЄКТС } \\
\end{array}$ & $\begin{array}{c}\text { Методика професійного } \\
\text { навчання } \\
5 \text { кр. ЄКТС }\end{array}$ & $\begin{array}{c}\text { Методика професійного } \\
\text { навчання } \\
5 \text { кр. ЄКТС }\end{array}$ & $\begin{array}{c}\text { Комунікативні процеси в } \\
\text { педагогічний діяльності } \\
3 \text { кр. ЄКТС }\end{array}$ \\
\hline $\begin{array}{c}\text { Історія Украйни та укр. } \\
\text { культури } \\
5 \text { кр. ЄКТС }\end{array}$ & $\begin{array}{l}\text { Іноземна мова } \\
3 \text { кр. ЄКТС }\end{array}$ & $\begin{array}{c}\text { Методичні засади } \\
\text { професійної освіти } \\
3 \text { кр. ЄКТС }\end{array}$ & $\begin{array}{l}\text { Tеорія машин та } \\
\text { механізмів } \\
5,5 \text { кр. ЄКТС }\end{array}$ & $\begin{array}{l}\text { Психологія праці } \\
\mathbf{3} \text { кр. ЄКТС }\end{array}$ & $\begin{array}{l}\text { Основи надійності та } \\
\text { довговічності машин } \\
4 \text { кр. ЄКТС }\end{array}$ & $\begin{array}{c}\text { Теоретично-планові основи } \\
\text { осіти } \\
4 \text { кр. ЄКТС }\end{array}$ & $\begin{array}{l}\text { Економіка підприемств і } \\
\text { маркетинг } \\
3 \text { кр. ЄКТС }\end{array}$ \\
\hline $\begin{array}{l}\text { Філософія техніки } \\
3 \text { кр. ЄКТС }\end{array}$ & $\begin{array}{c}\text { Українська мова (за } \\
\text { проф. спрямуванням) } \\
3 \text { кр. ЄКТС } \\
\text { TC }\end{array}$ & $\begin{array}{l}\text { Дидактичні основи } \\
\text { професійної освіти } \\
3 \text { кр. ЄКТС }\end{array}$ & $\begin{array}{c}\text { Методологія } \\
\text { стандартизація і } \\
\text { управління якістю } \\
3,5 \text { кр. ЄКТС } \\
\end{array}$ & $\begin{array}{l}\text { Електротехніка } \\
3 \text { кр. ЄКТС }\end{array}$ & $\begin{array}{l}\text { Автомобіль двигуни } \\
4 \text { кр. ЄКТС }\end{array}$ & $\begin{array}{c}\text { Ремонт транспортних } \\
\text { машин } \\
\text { 6 кр. ЄКТС }\end{array}$ & $\begin{array}{c}\text { Основи інженерно- } \\
\text { педагогічної творчості } \\
1,5 \text { кр. ЄКТС }\end{array}$ \\
\hline $\begin{array}{l}\text { Іноземна мова } \\
3 \text { кр. ЄКТС }\end{array}$ & $\begin{array}{c}\text { Інформатика та } \\
\text { обчислювальна техніка } \\
6 \text { кр. ЄКТС }\end{array}$ & $\begin{array}{l}\text { Опір матеріалів } \\
6 \text { кр. ЄКТС }\end{array}$ & $\begin{array}{l}\text { Гідравліка } \\
3 \text { кр. ЄКТС }\end{array}$ & $\begin{array}{l}\text { Деталі машин та } \\
\text { основи конструкцій } \\
5 \text { кр. ЄКТС }\end{array}$ & $\begin{array}{c}\text { Стратегія сталого } \\
\text { розвитку } \\
4 \text { кр. ЄКТС }\end{array}$ & $\begin{array}{c}\text { Основи сертифікації } \\
\text { автомобіля } \\
4 \text { кр. ЄКТС }\end{array}$ & $\begin{array}{c}\text { Креативні технології } \\
\text { навчання } \\
3,5 \text { кр. ЄКТС }\end{array}$ \\
\hline $\begin{array}{c}\text { Інженерна та } \\
\text { комп ютерна графіка } \\
3 \text { кр. ЄКТС }\end{array}$ & $\begin{array}{c}\text { Інженерна та } \\
\text { комп ютерна графіка } \\
3 \text { кр. ЄКТС }\end{array}$ & $\begin{array}{l}\text { Матеріалознавство } \\
3 \text { кр. ЄКТС }\end{array}$ & $\begin{array}{l}\text { Матеріалознавство } \\
3 \text { кр. ЄКТС }\end{array}$ & $\begin{array}{c}\text { Технологія } \\
\text { контруктивних } \\
\text { матеріалів } \\
3 \text { кр. ЄКТС } \\
\end{array}$ & $\begin{array}{l}\text { Технологічні основи } \\
\text { машинобудування } \\
3 \text { кр. ЄКТС }\end{array}$ & $\begin{array}{c}\text { Основи розр. розр і констр } \\
\text { транс машин } \\
4 \text { кр. ЄКТС }\end{array}$ & $\begin{array}{c}\text { Екологія транспорту } \\
\mathbf{4 , 5} \text { кр. ЄКТС }\end{array}$ \\
\hline $\begin{array}{l}\text { Вища математика } \\
6 \text { кр. ЄКТС }\end{array}$ & $\begin{array}{l}\text { Вища математика } \\
5 \text { кр. ЄКТС }\end{array}$ & $\begin{array}{l}\text { Вища математика } \\
3 \text { кр. ЄКТС }\end{array}$ & $\begin{array}{l}\text { Основи надійності та } \\
\text { довговічності } \\
\text { транспортних машин } \\
4 \text { кр. ЄКТС }\end{array}$ & $\begin{array}{c}\text { Відновлення деталей } \\
\text { машин } \\
4 \text { кр. ЄКТС }\end{array}$ & $\begin{array}{l}\text { Технічне обслугговування } \\
3 \text { кр. ЄКТС }\end{array}$ & $\begin{array}{l}\text { Автоматизація } \\
\text { транспортних машин } \\
\text { 6,5 кр. ЄКТС }\end{array}$ & $\begin{array}{c}\text { Експлуатація транспортних } \\
\text { машин } \\
\mathbf{3} \text { кр. ЄКТС }\end{array}$ \\
\hline $\begin{array}{c}\text { Фізика } \\
4 \text { кр. ЄКТС }\end{array}$ & $\begin{array}{c}\text { Фізика } \\
4 \text { кр. ЄКТС }\end{array}$ & $\begin{array}{l}\text { Теоретична механіка } \\
\text { 4,5 кр. ЄКТС }\end{array}$ & $\begin{array}{c}\text { Осн. розвитку, } \\
\text { розрахунку і констр. } \\
\text { транспорту } \\
3 \text { кр. ЄКТС } \\
\end{array}$ & $\begin{array}{l}\text { Теоретичні основи } \\
\text { теплотехніки } \\
3 \text { кр. ЄКТС }\end{array}$ & $\begin{array}{l}\text { Основи розв. розр і } \\
\text { констр транс машин } \\
3 \text { кр. ЄКТС }\end{array}$ & $\begin{array}{l}\text { Триботехніка } \\
\text { З кр. ЄКТС }\end{array}$ & $\begin{array}{l}\text { Основи фірмового } \\
\text { обслуговування } \\
4 \text { кр. ЄКТС }\end{array}$ \\
\hline \multirow[t]{5}{*}{$\begin{array}{c}\text { Хімія } \\
3 \text { кр. ЄКТС }\end{array}$} & $\begin{array}{l}\text { Екологія } \\
3 \text { кр. ЄКТС }\end{array}$ & $\begin{array}{c}\text { Курсова робота } \\
\text { Матеріалознавство }\end{array}$ & $\begin{array}{c}\text { Курсова робота } \\
\text { Основи надійності та } \\
\text { довговічності } \\
\text { транспортних засобів }\end{array}$ & $\begin{array}{c}\text { Особливості ТО і рем } \\
\text { автомобілів } \\
\text { 3,5 кр. ЄКТС }\end{array}$ & $\begin{array}{c}\text { Зносостійкі матеріали } \\
\text { З кр. ЄКТС }\end{array}$ & $\begin{array}{c}\text { Експлуатаційні метеріали } \\
3 \text { кр. ЄКТС }\end{array}$ & $\begin{array}{c}\text { Організація автосервісу } \\
3 \text { кр. ЄКТС }\end{array}$ \\
\hline & & $\begin{array}{l}\text { Розрахунково-графічна } \\
\text { робота опір матеріалів }\end{array}$ & $\begin{array}{c}\text { Навчальна практика } \\
3 \text { кр. ЄКТС }\end{array}$ & $\begin{array}{c}\text { Курсова робота } \\
\text { Деталі машин та } \\
\text { основи } \\
\text { конструювання } \\
\end{array}$ & $\begin{array}{c}\text { Курсова робота } \\
\text { Основи надійності та } \\
\text { довговічності } \\
\text { транспортних засобів }\end{array}$ & $\begin{array}{c}\text { Курсова робота } \\
\text { Ремонт транспортних } \\
\text { машин }\end{array}$ & $\begin{array}{c}\text { Курсова робота } \\
\text { Екологія транспорту }\end{array}$ \\
\hline & & & & $\begin{array}{c}\text { Курсова робота } \\
\text { відновлення деталей }\end{array}$ & $\begin{array}{c}\text { Курсова робота } \\
\text { Автомобільні } \\
\text { двигуни }\end{array}$ & $\begin{array}{c}\text { Розрахунково-графічна } \\
\text { робота } \\
\text { Основи розр. розр і констр } \\
\text { транс машин }\end{array}$ & $\begin{array}{c}\text { Курсовий проект } \\
\text { Експлуатація } \\
\text { транспортних } \\
\text { машин } \\
\end{array}$ \\
\hline & & & & & $\begin{array}{c}\text { Технологічна практика } \\
3 \text { кредата }\end{array}$ & $\begin{array}{c}\text { Курсова робота } \\
\text { Триботехніка }\end{array}$ & Педагогічна практика \\
\hline & & & & & & & Атестаційний екзамен \\
\hline
\end{tabular}

Мовні позначення :

Дисципліни природничонаукового спрямування Дисципліни гуманітарног
Дисципліни професійного спрямування (фахові технічні) Дисципліни професійного Проекти (курсові, розрахункові)
Економічна підготовка

Практики

Атестація
Рисунок 2 - Навчальний план підготовки бакалаврів денної форми навчання спеціальності 015.20 (Професійна освіта. Транспорт)

Національного транспортного університету (обов'язкова частина) [12] 


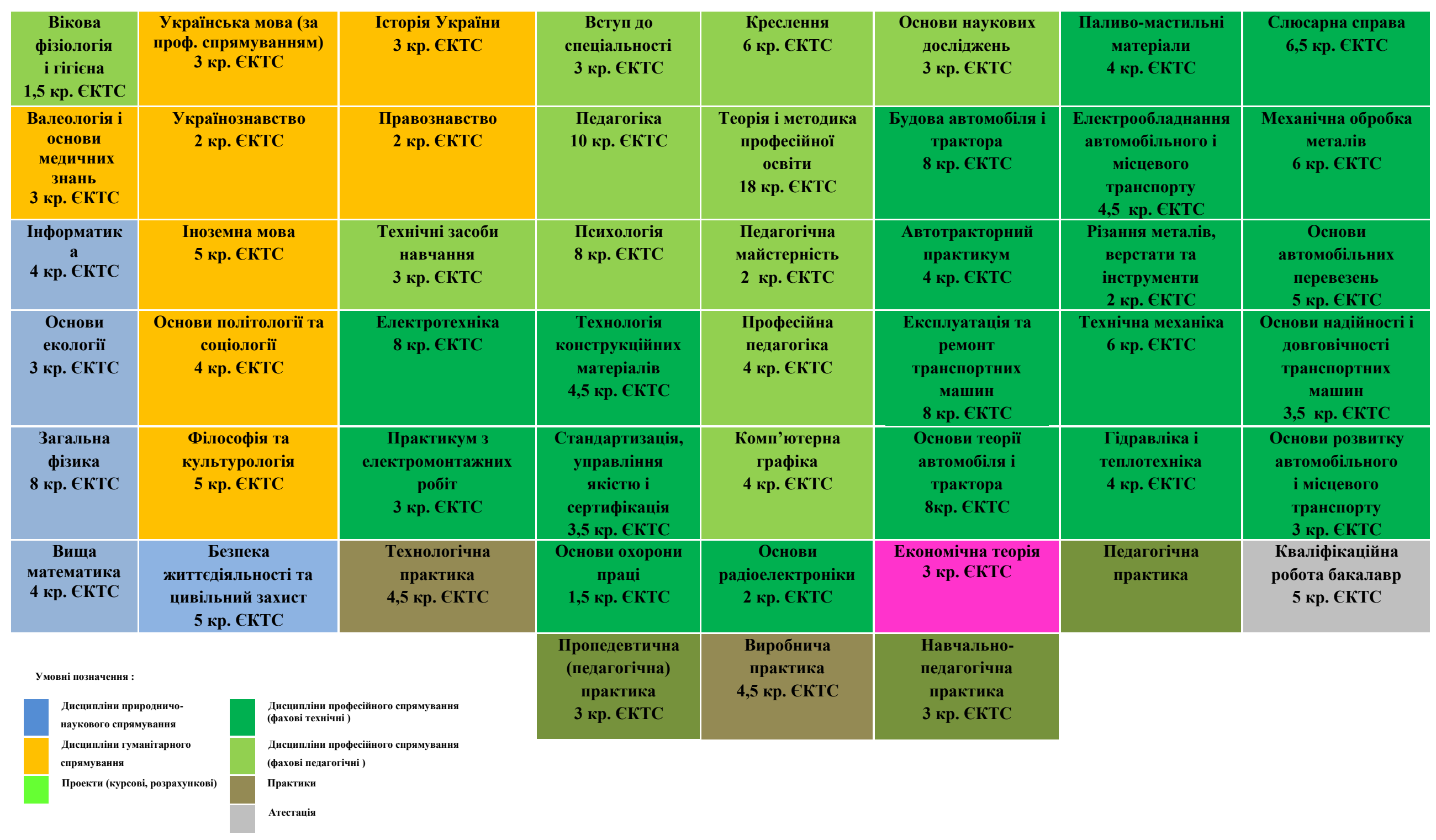

Рисунок 3 - Навчальний план підготовки бакалаврів денної форми навчання спеціальності 015.20 (Професійна освіта. Транспорт) Чернігівського національного педагогічного університету імені Т.Г. Шевченка [11] 
Педагогічна компетентність, як правило, формується в фахових дисциплінах психологічного та педагогічного спрямування, а саме «Вікова фізіологія і гігієна», «Психологія» i «Психологія праці» та педагогічного спрямування «Вступ до спеціальності», «Професійна педагогіка», «Методика професійного навчання». Перелік дисциплін природничо-наукового спрямування, який націлений на формування базових знань та умінь майбутніх фахівців та $є$ підгрунтям успішного засвоєння спеціальної підготовки автомобільного профілю, представлений, у переважній більшості, традиційними дисциплінами: «Вища математика», «Фізика», «Інженерна та комп’ютерна графіка», «Матеріалознавство» тощо. Водночас, кожен навчальний заклад, в межах академічної автономії, доповнює цей цикл власними дисциплінами, як «Безпека життєдіяльності» [6], «Основи екології» [11], «Хімія» [12] тощо.

В той же час, спеціальна компетентність формується при вивченні низки спеціальних дисциплін професійного спрямування: «Теорія машин та механізмів», «Опір матеріалів», «Технологія конструктивних матеріалів», «Гідравліка», «Деталі машин», «Автомобільні експлуатаційні матеріали», «Взаємозамінність, стандартизація і метрологія», «Основи надійності та довговічності машин», «Теоретична механіка», «Експлуатаційні матеріали», «Основи електротехніки», «Ремонт автомобіля», «Екологія транспорту», «Безпека руху» тощо.

Слід зазначити, що навчальні плани кожного ЗВО вирізняються певними особливостями. Так, наприклад, у ХНУ підготовка бакалаврів професійної освіти автотранспортного профілю містить фахову дисципліну «Технічне обслуговування автомобіля», яка передбачає вивчення теоретичного матеріалу курсу у закладі вищої освіти у поєднанні з практичною підготовкою студентів на підприємстві, що відбувається впродовж п’ятого та шостого навчальних семестрів і $\epsilon$, на нашу думку, прикладом започаткування елементів дуальної форми здобуття вищої освіти в українських ЗВО (рисунок 1).

3 метою забезпечення практичної підготовки бакалаврів професійної освіти навчальні плани усіх 3ВО містять різні види практик: навчально- 
технологічна, навчально-виробнича та виробничо-ремонтна (ХНУ), навчальна та технологічна практики (НТУ), технологічна і виробнича практики (ЧНПУ). При цьому, кількість кредитів на різні види практичної підготовки коливається в межах 6-26 (таблиця 1). Більшість проаналізованих ОПП передбачають формою підсумкового контролю за бакалаврською програмою - атестаційний іспит [6, 12], а ЧНТУ - кваліфікаційну роботу [11].

Таблиця 1: Аналіз змісту освітньо-професійних програм підготовки фахівців професійної освіти автотранспортного профілю у вітчизняних ЗВО

\begin{tabular}{|c|c|c|c|}
\hline Назва 3ВО & \multicolumn{3}{|c|}{ Кількість кредитів ЄКТС } \\
\hline Компоненти ОПП & HTУ & ЧНТУ & XHУ \\
\hline 1 & 2 & 3 & 4 \\
\hline $\begin{array}{l}\text { Дисципліни гуманітарного } \\
\text { спрямування }\end{array}$ & 14 & 27 & 20 \\
\hline $\begin{array}{l}\text { Дисципліни природничо- } \\
\text { наукового спрямування }\end{array}$ & 48 & 27 & 31 \\
\hline $\begin{array}{l}\text { Дисципліни професійного } \\
\text { спрямування (фахові технічні) }\end{array}$ & 125 & 94 & 124 \\
\hline $\begin{array}{l}\text { Дисципліни професійного } \\
\text { спрямування (фахові } \\
\text { педагогічні) }\end{array}$ & 39,5 & 61,5 & 23 \\
\hline Економічні науки & 3 & 3 & 3 \\
\hline \multicolumn{4}{|c|}{ Практики та форма атестації випускників } \\
\hline Навчальна & 3 & - & - \\
\hline Навчально-технологічна & 3 & 4,5 & 3 \\
\hline Навчально-педагогічна & - & 6 & - \\
\hline Педагогічна & 3 & 7,5 & 9 \\
\hline Навчально-виробнича & - & - & 3 \\
\hline Виробнича (ремонтна) & - & 4,5 & 7,5 \\
\hline Виробнича (стажувальна) & - & - & 6 \\
\hline Навчання на виробництві & - & - & 9 \\
\hline Атестація & 1,5 & 5 & 1,5 \\
\hline Разом & 240 & 240 & 240 \\
\hline Форми атестації & Атестаційний екзамен & $\begin{array}{c}\text { Кваліфікаційна } \\
\text { робота бакалавра }\end{array}$ & $\begin{array}{c}\text { Атестаційний } \\
\text { екзамен }\end{array}$ \\
\hline Академічна кваліфікація & $\begin{array}{c}\text { Фахівець в галузі } \\
\text { транспорту } \\
\end{array}$ & $\begin{array}{c}\text { Бакалавр в галузі } \\
\text { транспорту }\end{array}$ & $\begin{array}{c}\text { Бакалавр } \\
\text { професійної освіти }\end{array}$ \\
\hline Професійна кваліфікація & $\begin{array}{c}\text { Викладач практичного } \\
\text { навчання в галузі } \\
\text { транспорту }\end{array}$ & - & $\begin{array}{c}\text { Педагог } \\
\text { професійного } \\
\text { навчання. Механік }\end{array}$ \\
\hline
\end{tabular}


Після завершення навчання за освітньо-професійною програмою здобувачі вищої освіти у різних вітчизняних ЗВО можуть отримати одну 3 таких кваліфікацій (таблиця 1): бакалавр професійної освіти [6], бакалавр в галузі транспорту [11], фахівець в галузі транспорту [12]. У доповнення до визначених кваліфікацій ОПП Хмельницького національного університету передбачає здобуття професійної кваліфікації «механік» [6].

Для порівняння розглянемо досвід підготовки фахівців автотранспортного профілю Німеччини (на прикладі програм навчання «Промислова інженерія дуальна енергетична система»). Ця програма передбачає навчання студентів за однією із двох моделей дуального навчання: орієнтована на навчання, або практико-інтегроване навчання (рисунки 4 і 5 відповідно) [13].

Реалізація моделей дуального навчання розрахована на дев'ять семестрів і 210 кредитів СКТС. Зокрема, під час навчання за першою моделлю, орієнтованою на навчання, студенти набувають практичних навиків впродовж восьми навчальних семестрів, з яких перших п'ять - поєднують практичну діяльність на підприємствах галузі з теоретичним навчанням в умовах закладу вищої освіти, а в наступні три - поряд 3 вивченням економічних та фахових дисциплін залучаються до практичного навчання i участі у практичному семінарі. Завершується навчання у дев'ятому семестрі виконанням та захистом бакалаврської роботи.

Особливістю другої практико-інтегрованої моделі дуального навчання є чергування практичного навчання в компанії, що триває впродовж двох перших років, та навчання у закладі вищої освіти. Після дванадцяти місяців практичного навчання студенти здають проміжний іспит, а ще через дев'ять - підсумковий в Ремісничій палаті (die Handwerkskammern, HWK). Завершальний етап навчання за практико-інтегрованою моделлю передбачає виконання та захист дисертації у поєднанні зі здачею колоквіуму. 


\begin{tabular}{|c|c|c|c|c|c|c|c|c|}
\hline 1 Семестр & 2 Семестр & 3 Семестр & 4 Семестр & 5 Семестр & 6 Семестр & 7 Семестр & 8 Семестр** & 9 Семестр *** \\
\hline $\begin{array}{c}\text { Математика } 1 \\
6 \text { кр. ЄКТС }\end{array}$ & $\begin{array}{c}\text { Математика } 2 \\
6 \text { кр. ЄКТС }\end{array}$ & $\begin{array}{l}\text { Прнродничі } \\
\text { науки } \\
6 \text { кр. ЄКТС }\end{array}$ & $\begin{array}{l}\text { Управління } \\
\text { проектами } \\
6 \text { кр. ЄКТС }\end{array}$ & $\begin{array}{l}\text { Прнкладна } \\
\text { статистика } \\
6 \text { кр. ЄКТС }\end{array}$ & $\begin{array}{c}\text { Вимірювальний } \\
\text { і технологія } \\
\text { автоматизації } \\
6 \text { кр. ЄКТС }\end{array}$ & $\begin{array}{l}\text { Механіка рідини } \\
\text { (англійська) } \\
6 \text { кр. ЄКТС }\end{array}$ & $\begin{array}{l}\text { Інформація та } \\
\text { комунікаційні } \\
\text { технології } \\
6 \text { кр. ЄКТС }\end{array}$ & $\begin{array}{c}\text { Модуль } 5 \\
6 \text { кр. ЄКТС }\end{array}$ \\
\hline $\begin{array}{l}\text { Енергетичні } \\
\text { системи та } \\
\text { енергія } \\
6 \text { кр. ЄКТС }\end{array}$ & $\begin{array}{l}\text { Електротехнік } \\
6 \text { кр. ЄКТС }\end{array}$ & $\begin{array}{l}\text { Технічна } \\
\text { механіка } \\
6 \text { кр. ЄКТС }\end{array}$ & $\begin{array}{l}\text { Термодннаміка } \\
6 \text { кр. ЄКТС }\end{array}$ & $\begin{array}{c}\text { Технологія } \\
\text { електричної енергіi } \\
6 \text { кр. ЄКТС }\end{array}$ & $\begin{array}{c}\text { Економіка } 3 \\
6 \text { кр. ЄКТС }\end{array}$ & $\begin{array}{c}\text { Основи } \\
\text { інформатики } \\
\text { та мови } \\
\text { програмування } \\
6 \text { кр. ЄКТС }\end{array}$ & $\begin{array}{c}\text { Економіка } 4 \\
6 \text { кр. ЄКТС }\end{array}$ & $\begin{array}{c}\text { Модуль } 6 \\
6 \text { кр. ЄКТС }\end{array}$ \\
\hline $\begin{array}{c}\text { Економіка } 1 \\
6 \text { кр. ЄКТС }\end{array}$ & $\begin{array}{c}\text { Господарське } \\
\text { право } 1 \\
6 \text { кр. ЄКТС }\end{array}$ & $\begin{array}{l}\text { Господарське } \\
\text { право } 2 \\
6 \text { кр. ЄКТС }\end{array}$ & $\begin{array}{c}\text { Економіка } 2 \\
6 \text { кр. ЄКТС }\end{array}$ & $\begin{array}{l}\text { Перетворення } \\
\text { енергії } \\
\text { та зберігання } \\
6 \text { кр. ЄКТС }\end{array}$ & $\begin{array}{l}\text { Модуль } 1 \\
6 \text { кр. ЄКТС }\end{array}$ & $\begin{array}{c}\text { Модуль } 3 \\
6 \text { кр. ЄКТС }\end{array}$ & $\begin{array}{c}\text { Модуль } 4 \\
6 \text { кр. СКТС }\end{array}$ & $\begin{array}{c}\text { Модуль } 7 \\
6 \text { кр. ЄКТС }\end{array}$ \\
\hline & Практич & діяльність & & & $\begin{array}{l}\text { Модуль } 2 \\
6 \text { кр. ЄКТС }\end{array}$ & \multicolumn{2}{|c|}{$\begin{array}{c}\text { Практнчннй семестр } \\
\text { та практнчннй семінар } 26+2 \\
\text { кредити }\end{array}$} & $\begin{array}{c}\text { Бакалаврська } \\
\text { робота та } \\
\text { колоквіум } \\
12+2 \text { кр. ЄКТС }\end{array}$ \\
\hline
\end{tabular}

Умовні позначення :

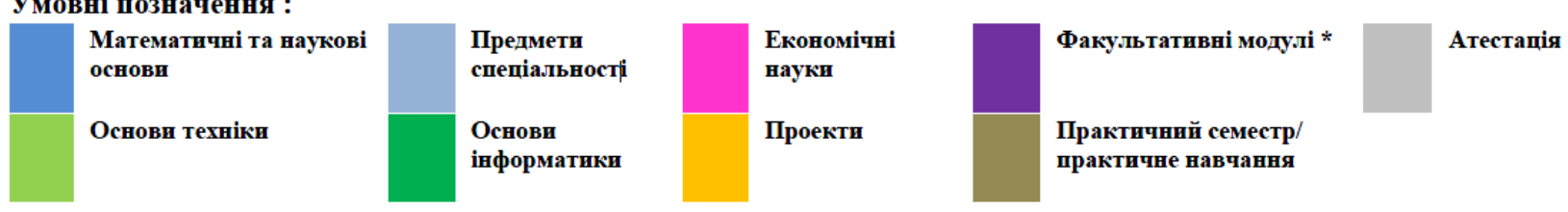

Рисунок 4 - Дипломна програма: промислова інженерія - дуальна енергетична система (орієнтована на навчання) бакалавра інженерних наук В.Eng. [13] 


\begin{tabular}{|c|c|c|c|c|c|c|c|c|}
\hline 1 Семестр & 2 Семестр & 3 Семестр & 4 Семестр & 5 Семестр & 6 Семестр & 7 Семестр & 8 Семестр** & 9 Семестр** \\
\hline $\begin{array}{l}\text { Математика } 1 \\
6 \text { кр. ЄКТС }\end{array}$ & $\begin{array}{c}\text { Математика } 2 \\
6 \text { кр. ЄКТС }\end{array}$ & $\begin{array}{l}\text { Природничі } \\
\text { науки } \\
6 \text { кр. ЄКТС }\end{array}$ & $\begin{array}{c}\text { Теплодинаміка } \\
6 \text { кр. ЄКТС }\end{array}$ & $\begin{array}{l}\text { Прикладна } \\
\text { статистика } \\
6 \text { кр. ЄКТС }\end{array}$ & $\begin{array}{c}\text { Управління } \\
\text { проектом } \\
6 \text { кр. ЄКТС }\end{array}$ & $\begin{array}{c}\text { Основи } \\
\text { інформатики } \\
\text { та мови } \\
\text { програмування } \\
6 \text { кр. ЄКТС }\end{array}$ & \multirow{2}{*}{\multicolumn{2}{|c|}{$\begin{array}{c}\text { Практичний семестр } \\
\text { та практичний семінар } \\
26+2 \text { кр. ЄКТС }\end{array}$}} \\
\hline $\begin{array}{c}\text { Енергетичні } \\
\text { системи } \\
\text { та енергія } \\
6 \text { кр. ЄКТС }\end{array}$ & $\begin{array}{c}\text { Електротехніка } \\
6 \text { кр. ЄКТС }\end{array}$ & $\begin{array}{l}\text { Природничі } \\
\text { науки } \\
6 \text { кр. ЄКТС }\end{array}$ & $\begin{array}{c}\text { Господарське } \\
\text { право } 1 \\
6 \text { кр. ЄКТС }\end{array}$ & $\begin{array}{c}\text { Механіка рідини } \\
\text { (англійська) } \\
6 \text { кр. ЄКТС }\end{array}$ & $\begin{array}{c}\text { Вимірювальння } \\
\text { і технологія } \\
\text { автоматизації } \\
6 \text { кр. ЄКТС }\end{array}$ & $\begin{array}{c}\text { Модуль } 3 \\
6 \text { кр. ЄКТС }\end{array}$ & & \\
\hline \multirow[t]{3}{*}{$\begin{array}{c}\text { Економіка } 1 \\
6 \text { кр. ЄКТС }\end{array}$} & $\begin{array}{c}\text { Економіка } 2 \\
6 \text { кр. ЄКТС }\end{array}$ & \multirow{3}{*}{\multicolumn{2}{|c|}{$\begin{array}{c}\text { Практичне навчання } \\
\text { в компанії }\end{array}$}} & $\begin{array}{c}\text { Господарське } \\
\text { право } 2 \\
6 \text { кр. ЄКТС }\end{array}$ & $\begin{array}{c}\text { Економіка } 3 \\
6 \text { кр. ЄКТС }\end{array}$ & $\begin{array}{c}\text { Модуль } 4 \\
6 \text { кр. ЄКТС }\end{array}$ & $\begin{array}{c}\text { Основи } \\
\text { інформатики } \\
\text { та мови } \\
\text { програмування } \\
6 \text { кр. ЄКТС }\end{array}$ & \multirow{3}{*}{ 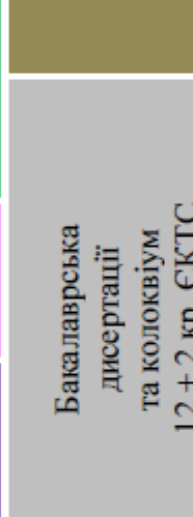 } \\
\hline & \multirow{2}{*}{ Практичне } & & & $\begin{array}{c}\text { Перетворення } \\
\text { енергії } \\
\text { та зберігання } \\
6 \text { кр. ЄКТС }\end{array}$ & $\begin{array}{l}\text { Модуль } 1 \\
6 \text { кр. ЄКТС }\end{array}$ & $\begin{array}{l}\text { Модуљь } 5 \\
6 \text { кр. ЄКТС }\end{array}$ & $\begin{array}{l}\text { Економіка } 3 \\
6 \text { кр. ЄКТС }\end{array}$ & \\
\hline & & & & $\begin{array}{c}\text { Технологія } \\
\text { електричної } \\
\text { енергії } \\
6 \text { кр. ЄКТС }\end{array}$ & $\begin{array}{l}\text { Модуль } 2 \\
6 \text { кр. ЄКТС }\end{array}$ & $\begin{array}{l}\text { Модуль } 6 \\
6 \text { кр. ЄКТС }\end{array}$ & $\begin{array}{l}\text { Модуль } 7 \\
6 \text { кр. ЄКТС }\end{array}$ & \\
\hline
\end{tabular}

Умовні познатення :

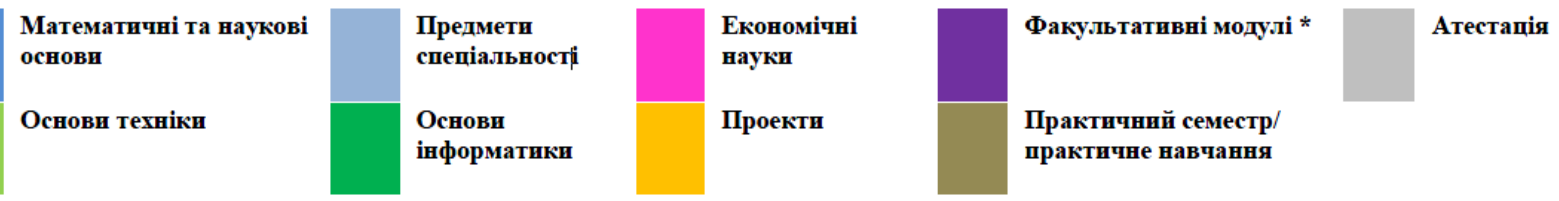

Рисунок 5 - Дипломна програма: промислова інженерія - дуальна енергетична система (практико-інтегрована) бакалавра інженерних наук B.Eng. [13] 
При цьому, студент, який навчався за моделлю орієнтованою на навчання, отримує ступень бакалавра інженерно-технічних наук та документ про набуття практичних навиків, який видає Торгово-промислова палата Німеччини за умови обов'язкового складання підсумкового іспиту.

Отже, як бачимо обсяги практичної підготовки майбутніх німецьких фахівців автомобільного транспорту суттєво переважають сумарні обсяги практик вітчизняних ОПП. Постійний зв'язок студента з реальним виробництвом сприяє підвищенню їх мотивації до набуття практичних навичок для подальшої роботи; працевлаштуванню випускників, залученню керівників підприємств до практичного навчання майбутніх працівників. Відтак, дуальна форма здобуття освіти відповідає інтересам усіх учасників освітнього процесу та стейхолдерів.

Досвід підготовки бакалаврів автотранспортного профілю Німеччини із використанням дуальної форми здобуття освіти свідчить про існування суттєвих переваг такого навчання. Удосконалення освітнього процесу за рахунок впровадження дуальних програм підготовки бакалаврів дасть можливість: усунути розрив між теоретичним навчанням та практичною складовою підготовки майбутніх фахівців;

Водночас, поєднання теоретичного навчання та практичної роботи за дуальними програмами призводить до: збільшення як фізичного так і психічного навантаження на студента під час навчання, обмежує його в свободі вибору навчальних дисциплін, знижує рівень наукових досліджень серед студентства.

Висновки і перспективи подальших розвідок.

Отже, враховуючи прогресивний досвід Німеччини щодо використання дуальних освітніх програм у вищій освіті, доцільно започаткувати підготовку бакалаврів професійної освіти автотранспортного профілю за дуальною формою здобуття освіти у вітчизняних 3ВО. Така форма здобуття вищої освіти сприятиме набуттю студентами великого практичного досвіду ще під час навчання та гарантованого працевлаштування після його завершення. Дуальна модель навчання сприятиме підвищенню рівня підготовки майбутніх фахівців відповідно 
до вимог сучасного ринку праці та їх успішній адаптації в умовах реального виробництва.

Поєднання теоретичного навчання із практичною підготовкою дозволить модернізувати вищу професійну освіти шляхом підсилення iї практичної складової. Впровадження передового міжнародного досвіду обумовлює створення освітніх практико-орієнтованих програм нового типу, так званих дуальних програм підготовки фахівців. Перспективними напрямами подальших досліджень вважаємо детальне вивчення закордонного досвіду щодо організації освітнього процесу підготовки бакалаврів за дуальною формую здобуття освіти та особливостей нормативної бази, на якій буде базуватися реалізації дуальних програм.

\section{References}

1. Dualna forma zdobuttia vyshchoi ta fakhovoi pered vyshchoi osvity [Dual Form of Higher Education and Professional Higher Education] [Electronic resource]. Exposure Draft (MSE order from 13.02.2019 № 175) // Ministerstvo osvity i nauky Ukrainy. - Access mode : https://mon.gov.ua/ua/ [in Ukrainian].

2. Kremen, V. H., Zakharchenko, V. M., Luhovyi, V. I., Rashkevych, Yu. M., Talanova Zh. V. (2014) Rozroblennia osvitnikh prohram. Metodychni rekomendatsii [Development of Educational Programs. Guidelines]. Kyiv, Ukraine. [in Ukrainian].

3. Rashkevych, Yu. M. (2018) Metodychni rekomendatsii shchodo opysu osvitnoi prohramy v konteksti novykh standartiv vyshchoi osvity [Guidelines for Describing the Educational Program in the Context of New Higher Education Standards] [Electronic resource]. - Access mode : https://pedpresa.ua. [in Ukrainian].

4. Hryzun, L. E. (2018) Formuvannia zmistu vyshchoi profesiinoi osvity za umov suchasnykh osvitnikh tendentsii [The Content Formation of Higher Professional Education in the Context of Modern Educational Trends] [Electronic resource]. Access mode : https://www.google.com/search?qutf-8\&oe=utf-8\&client=firefox-b. [in Ukrainian].

5. Luhovyi, V. I. (2014) Zabezpechennia yakosti vyshchoi osvity [Higher education quality assurance]. Legal Framework for the Implementation of the Bologna Process in Ukraine. Kyiv, Ukraine. [in Ukrainian].

6. Khmelnytskyi natsionalnyi universytet. Osvitnia prohrama 015 Profesiina osvita. Transport [Khmelnytskyi National University. Educational Program 015 Professional Education. Transport]. [Electronic resource]. - Access mode : https://www.khnu.km.ua/root/page.aspx?l=0\&r=50\&p=1\&f=\%D0\%91. [in Ukrainian]. 
7. Hulai, O. I. (2018) Osoblyvosti stupenevoi pidhotovky maibutnikh inzheneriv [Features of the Future Engineers Degree Training]. Physical and Mathematical Education, Vol. 1 (15). [in Ukrainian].

8. Standart vyshchoi osvity za spetsialnistiu 015 «Profesiina osvita» [Higher Education Standard in Major 015 "Vocational Education”]. [Electronic resource]. Access mode : https://mon.gov.ua. [in Ukrainian].

9. Pro vyshchu osvitu [Higher Education Act 01.07.2014 № 1556-VII]. [Electronic resource]. - Access mode : https://zakon.rada.gov.ua/laws/show/1556-18. [in Ukrainian].

10. Kankovskyi, I. Ie. (2014) Systema profesiinoi pidhotovky inzhenerivpedahohiv avtotransportnoho profiliu [The System of Professional Training of Engineers-Educators of Automotive Profile]. Khmelnytskyi, Ukraine. [in Ukrainian].

11. Chernihivskyi natsionalnyi pedahohichnyi universytet imeni T. H. Shevchenka osvitno-profesiina prohrama 015 Profesiina osvita Transport [Chernihiv National Pedagogical University named after Shevchenko T. G. Educational and Professional Program 015 Professional Education. Transport] [Electronic resource]. - Access mode: https://drive.google.com/file/d/1z- 0lKnydnwCF5qHLIwsi5ql3R24mLRNo/view [in Ukrainian].

12. Natsionalnyi transportnyi universytet robochyi navchalnyi plan studenta spetsialnosti 015 Profesiina osvita. Transport [National University of Transportation. Curriculum for the Major 015 Vocational education. Transport] [Electronic resource]. - Access mode : http://vstup.ntu.edu.ua/navch-plan/FEP-015profosvita.pdf. [in Ukrainian].

13. Bachelor-Abschluss in Wirtschaftsingenieurwesen - Energiesysteme [Bachelor's Degree in Industrial Engineering - Energy Systems] [Electronic resource]. - Access mode : https://www.hochschule-ruhrwest.de/studium/studienangebot/bachelor/wirtschaftsingenieurwesen-energiesysteme/ [in German].

Translation of the Title, Name and References to the Author's Language

\title{
Зміст та структура підготовки бакалаврів за дуальною формою здобуття освіти: український та німецький досвід
}

\author{
Храпач Дмитро \\ Аспірант, Хмельницький національний університет \\ (Хмельницький, Україна) \\ Красильникова Ганна \\ Доктор педагогічних наук, професор \\ Хмельницький національний університет \\ (Хмельницький, Україна)
}




\section{Анотація}

Стаття присвячена компаративному аналізу вітчизняного та зарубіжного досвіду створення дуальних освітніх програм підготовки бакалаврів на прикладі спеціальностей галузі автомобільного транспорту. Схарактеризовані структура та змістове наповнення освітньо-професійних програм підготовки бакалаврів професійної освіти автотранспортного профілю провідних вітчизняних ЗВО. Визначені основні види практик як компоненти освітніх програм, націлені на практичну підготовку майбутніх бакалаврів професійної освіти з автомобільного транспорту. Висвітлена практика створення освітньопрофесійних програм з елементами дуальної освіти окремими вітчизняними закладами шляхом опанування на виробництві низки спеціальних дисциплін. Представлений німецький досвід створення дуальних програм підготовки фахівців автомобільного транспорту, реалізація яких відбувається за однією із двох моделей дуального навчання: орієнтованої на навчання або практикоінтегрованого навчання. Схарактеризовані особливості реалізації дуальних моделей: орієнтованої на навчання - постійна практична підготовка на підприємстві у поєднанні 3 теоретичним навчанням в закладі освіти; практикоінтегрованого навчання - чергування періодів практичного навчання в компанії та навчання у закладі освіти. Визначені переваги використання дуальних програм підготовки фахівців автомобільного транспорту та висвітлені перспективи подальшого розвитку дуальної форми здобуття вищої освіти в Україні.

Ключові слова: вища освіта, дуальна форма здобуття освіти, дуальна програма, структура навчального плану.

\section{Лimepamypa}

1. Дуальну форма здобуття вищої та фахової перед вищої освіти [Електронний ресурс] : Проект положення (наказ МОН від 13.02.2019 № 175) // Офіційний сайт Міністерства освіти і науки України. -Режим доступу: https://mon.gov.ua/ua/ . 
2. Розроблення освітніх програм. Методичні рекомендації / Авт.: В.М. Захарченко, В.І. Луговий, Ю.М. Рашкевич, Ж.В. Таланова / За ред. В.Г. Кременя. - К. : ДП «НВЦ «Пріоритети», 2014. - 120 с.

3. Рашкевич Ю.М. Методичні рекомендації щодо опису освітньої програми в контексті нових стандартів вищої освіти [Електронний ресурс]. Режим доступу: https://pedpresa.ua.

4. $\quad$ Гризун Л. Е. Формування змісту вищої професійної освіти за умов сучасних освітніх тенденцій [Електронний ресурс]. - Режим доступу: https://www.google.com/search?qutf-8\&oe=utf-8\&client=firefox-b.

5. Луговий В.І. Забезпечення якості вищої освіти / В. Луговий // Правові засади реалізації Болонського процесу в Україні: монографія / Колектив авторів: Бугров В., Гожик А., Жданова К., Зарубінська І., Захарченко В., Калашнікова С., Козієвська О., Линьова І., Луговий В., Оржель О., Рашкевич Ю., Таланова Ж., Шитікова С.; за заг. ред. В. Лугового, С. Калашнікової. - К.: ДП «НВЦ «Пріоритети», 2014. - 156 с. - С. 65-95.

6. Хмельницький національний університет освітня програма 015 Професійна освіта. Транспорт [Електронний ресурс] :- Режим доступу: https://www.khnu.km.ua/root/page. aspx $? 1=0 \& \mathrm{r}=50 \& \mathrm{p}=1 \& \mathrm{f}=\% \mathrm{D} 0 \% 91$.

7. Гулай O.I. Особливості ступеневої підготовки майбутніх інженерів. Фізико-математична освіта. 2018. Випуск 1(15). С. 176-180.

8. Стандарт вищої освіти за спеціальністю 015 «Професійна освіта» [Електронний ресурс] : - Режим доступу: https://mon.gov.ua.

9. Про вищу освіту [Електронний ресурс] : Закон України від 01.07.2014 № 1556-VII // Законодавство України / Верхов. Рада України. - Текст. дані. - Київ, 2014. - Режим доступу: https://zakon.rada.gov.ua/laws/show/1556-18.

10. Каньковський I.С. Система професійної підготовки інженерів-педагогів автотранспортного профілю: монографія / Ігор Євгенійович Каньковський; за ред..Н.Г. Ничкало. - Хмельницький: ФОП Цасюк А.А., 2014. 562 с.

11. Чернігівський національний педагогічний університет імені Т.Г. Шевченка освітньо-професійна програма 015 Професійна освіта. Транспорт 
[Електронний ресурс]:- Режим доступу: https://drive.google.com/file/d/1z01KnydnwCF5qHLIwsi5ql3R24mLRNo/view

12. Національний транспортний університет робочий навчальний план студента спеціальності 015 Професійна освіта. Транспорт [Електронний ресурс]:Режим доступу: http://vstup.ntu.edu.ua/navch-plan/FEP-015profosvita.pdf

13. Bachelor-Abschluss in Wirtschaftsingenieurwesen - Energiesysteme [Eine elektronische Ressource]: - Zugriffsmodus: https://www.hochschule-ruhrwest.de/studium/studienangebot/bachelor/wirtschaftsingenieurwesen-energiesysteme/ 